\title{
THE USERS PERCEPTION OF MOBILE APPS OF POLISH BIGGEST SERVICE COMPANIES
}

\author{
LESZEK GRACZ \\ University of Szczecin, Faculty of Management and Economics of Services, POLAND \\ e-mail: leszek.gracz@wzieu.pl
}

\begin{abstract}
\begin{tabular}{l|l} 
RECEIVED & 10 December 2018
\end{tabular}
\begin{tabular}{l|l} 
ACCEPTED & 28 December 2018
\end{tabular}

JEL

CLASSIFICATION

M31, M37

KEYWORDS apps, mobile marketing, service companies

ABSTRACT The use of smartphones is still increasing in Poland. $64 \%$ of Poles used a smartphone device in 2017. Mobile marketing is therefore an ever increasingly important component of a firm's overall promotional strategy. The importance of this medium can be seen through time spent on mobile media, number of searches, and direct and indirect mobile generated sales. The objective of the paper is to investigate the perception of the use of mobile apps by the biggest Polish service companies. By the use of a dedicated research tool, the paper investigates changes that occurred during the two years period. It was revealed that the mean evaluation of mobile apps by android users declined in the research period (years 2016-2018). It constitutes a serious thread for researched service companies, as it may indicate a poor level of satisfaction of their customers from their mobile marketing actions.
\end{abstract}

\section{Introduction}

The use of smartphones is still increasing in Poland. According to the report "Polska jest mobi" [Poland is mobi] $64 \%$ of Poles used a smartphone device in 2017. Although, according to this report there is not recorded a dynamic growth of smartphone penetration (as it happened in previous years), there can be observed a noticeably grow of intensity of use of the "mobile" channel. Therefore mobile marketing is an ever increasingly important 
component of a firm's overall promotional strategy. The importance of this medium can be seen through time spent on mobile media, number of searches, and direct and indirect mobile generated sales (Berman, 2016, p. 432). Many marketing studies have shown that mobile channels bring value to customers and improve operating efficiency (Qin, Tang, Jang, Lehto, 2017, p. 174). A crucial aspect of a mobile channel are the mobile apps offered to customers. The objective of the paper is to investigate the perception of the use of mobile apps by the biggest Polish service companies. By the use of a dedicated research tool, the paper investigates changes that occurred during the two years period. The importance of the study is based on the assumption, that understanding how and why consumers engage with mobile apps is critical to the success of ubiquitous mobile marketing (Kim, Baek, 2018, p. 148).

\section{Mobile marketing concept}

According to the Mobile Marketing Association (2018) "Mobile marketing is a set of practices that enables organizations to communicate and engage with their audience in an interactive and relevant manner through and with any mobile device or network." In the definition the "set of practices" includes a wide variety of activities, such as advertising and media, direct response, promotions, relationship management, CRM, customer services, loyalty creation and maintaining, social marketing - in general any marketing actions. The other part of the definition includes "communication" and "engagement". The engagement reflects the creation and maintaining of relationships, generation of activities, stimulating social interaction and be present at a time a consumer expresses a need. This part refers to widely understood relations, a basic for modern approach to marketing. As it can be seen, this definition of mobile marketing emphasis the marketing actions implemented on mobile device. Therefore, for the purpose of this paper the author defines mobile marketing as "all marketing activities using mobile device, medium or technology as channel for reaching receivers" (Gracz, 2016, p. 34).

In particular, these activities include: apps, mobile websites, photocodes (QR code), sms/mms marketing, geolocation, augmented reality, mobile advertising (display, video and others). This paper focuses on one of the mobile marketing activity: the mobile apps.

\section{The role of apps - literature analysis}

Mobile phone applications (apps) are specific m-marketing tools designed for the interchange of information, networking, and leisure (Kuan-Yu, Yu-Lun, 2012, p. 116). D.G. Taylor, T.A. Voelker, I. Pentina (2011, p. 61), defines mobile apps as small programs that run on a mobile device and perform tasks ranging from banking to gaming and web browsing. According to Deepak Kumar, Keyoor Purani and Shyam Viswanathan apps are software programs that are installed in a mobile device, and which often display an identity of the brand (Kumar, Purani, Viswanathan, 2018, p. 133)

The five main objectives of branded mobile apps, according to Zhenzhen Zhao and Christine Balague (2015, pp. 306-307) are:

- communication,

- CRM,

- sales,

- product innovation,

- and marketing research. 
The authors note that individual branded apps can have more than one business objective and individual brands can design multiple mobile apps to target different products and business goals.

The special interest in the paper is put on mobile apps designed by companies for marketing purposes. The mobile apps have become important marketing stimuli in shaping customers' brand experience in $\mathrm{m}$-commerce. The high level of mobile usage has resulted in a plethora of mobile applications used increasingly by businesses for multiple marketing purposes that help manage customer relationships including precision targeting, acquisition, loyalty and retention management (Pentina, Zhang, Bata, Chen, 2016, p. 410). The instituting and maintenance of mobile apps have become a vital part of mobile marketing strategy of many companies who want to expose app users to brands in innovative and effective ways (Liu, Zhao Li, 2017, p. 71).

\section{Research method}

The instituting and maintenance of mobile apps have become a vital part of mobile marketing strategy of many companies who want to expose app users to brands in innovative and effective ways. The research method for analyzing the perception of mobile apps of Polish biggest service companies is a research that has been conducted for two years. The first choice of companies made on 2015 using a well known and established ranking: "Lista 500 Największe Firmy Rzeczypospolitej 2104" (the list of 500 biggest enterprises according to "Reczpospolita" newspaper from 2014). Out of 20 biggest enterprises 12 service companies were indicated, namely: 8 banks (PKO BP SA; Bank Pekao SA; Bank Zachodni WBK SA; mBank SA; ING Bank Śląski SA; Bank Handlowy w Warszawie SA; Bank Millennium SA; Getin Noble SA), 1 insurance company (PZU SA) and 3 mobile phone operators (Polkomtel SA; T-Mobile Polska SA; PTK Centertel sp. z 0.o. - Orange Polska SA).

The study was focused on Android as it is an operating system with the largest market share in Poland (and in the world).

The first data was collected on January 2016, by searching the Google Play store with the phrases of the names of the companies. The research was conducted in using Google Chrome Version 43.0.2357.124 m, with the use of incognito mode to prevent any possible disruptions in searching. The research results were then analyzed by choosing the most popular/mostly used apps. The following aspects were recorded:

- the number of total results occurring after searching by a company name,

- the number of official apps offered by a company (the apps that were not created or offered by a company, e.g. fan apps, were not considered); in case a company operates on market using many brands all brands were taken into account,

- the type of app created by (or ordered by) the particular company (if applicable),

- the mean evaluation in Google Play store (if applicable)

- the number of comments,

- the number of downloads.

The research was repeated in October 2018, with the use of Google Chrome Version 70.0.3538.110, with the use of incognito mode to prevent any possible disruptions in searching. The same category of data was collected. As some of the apps changed during that period (for example a company changed their brand and introduced a new app or the old app was removed and replaced with an entirely new one), only the apps that existed both in January 2016 and October 2018 were taken into account. 
The aspect that is especially taken into account is the mean evaluation in Google Play store. As it is done by users themselves, it can be treated as an indicator of consumers' overall satisfaction with the app. It is based on the mechanism that allows users to rate releases using scores (i.e., star ratings) and text reviews. The former (i.e., the score) is usually expressed as a choice of one to five stars, and the latter (i.e., the review) is a free text description that does not have a predefined structure and is used to describe informally bugs and desired features. The review is also used to describe impressions, positions, comparisons, and attitudes toward the apps (Palomba et al., 2018, p. 150). Therefore it may be concluded, that the mean evaluation of an app presents the overall attitude of consumers towards this app. The aspect that is research in the paper is the difference in the mean score achieved by the apps within 2 years period.

\section{Research results}

Out of the eight banks (PKO BP SA; Bank Pekao SA; Bank Zachodni WBK SA; mBank SA; ING Bank Ślaski SA; Bank Handlowy w Warszawie SA; Bank Millennium SA; Getin Noble SA) researched in 2016, seven were considered in 2018, as one bank (Bank Zachodni WBK SA) rebranded during that time and introduced a new app, which made it not possible to compare with 2016. The results of the comprehension between 2016 and 2018 are presented in Table 1.

Table 1. The comprehension of the mean evaluation of the most popular apps created by 7 biggest Polish banks

\begin{tabular}{|c|c|c|c|c|c|}
\hline \multirow[b]{2}{*}{ The name of the company } & \multirow[b]{2}{*}{ Name of the app } & \multirow[b]{2}{*}{ Category } & January 2016 & August 2018 & \multirow{2}{*}{$\begin{array}{c}\text { Change } \\
\text { in the mean } \\
\text { evaluation }\end{array}$} \\
\hline & & & \multicolumn{2}{|c|}{$\begin{array}{c}\text { mean evaluation } \\
(1-\text { very bed, } 5-\text { very good })\end{array}$} & \\
\hline \multirow{3}{*}{ PKO BP SA } & IKO & finance & 4.4 & 4.7 & 0.3 \\
\hline & supermakler mobile & finance & 3.3 & 3.0 & -0.3 \\
\hline & Token iPKO biznes & finance & 4.1 & 3.7 & -0.4 \\
\hline \multirow{4}{*}{ Bank Pekao SA } & PeoPay & finance & 4.2 & 3.7 & -0.5 \\
\hline & PekaoToken & finance & 4.2 & 3.6 & -0.6 \\
\hline & PekaoBiznes24 & finance & 4.1 & 3.7 & -0.4 \\
\hline & Mobilny Planer Zakupów & finance & 3.8 & 3.6 & -0.2 \\
\hline \multirow{2}{*}{ mBank SA } & mBank PL & finance & 4.1 & 4.6 & 0.5 \\
\hline & Program Partnerski mBanku & finance & 4.6 & 4.1 & -0.5 \\
\hline \multirow{2}{*}{ ING Bank Śląski SA } & INGBusiness & finance & 4.0 & 2.8 & -1.2 \\
\hline & INGMobile & finance & 4.7 & 3.8 & -0.9 \\
\hline Bank Handlowy w Warszawie SA & Citi Handlowy & finance & 3.4 & 2.9 & -0.5 \\
\hline \multirow{2}{*}{ Bank Millennium SA } & Bank Millennium & finance & 4.6 & 4.6 & 0.0 \\
\hline & Bank Millennium Firmy & finance & 3.5 & 3.3 & -0.2 \\
\hline Getin Noble SA & Getin Mobile & finance & 3.8 & 4.1 & 0.3 \\
\hline
\end{tabular}

Source: own research.

There is a clear trend in the evaluation of the most popular apps created by 7 biggest Polish banks: most of them are declining. There are some notable exceptions, namely IKO app by PKO BP SA increased the mean evaluation from 4.4 to 4.7 (which can be named a very good result); the mBank PL app by mBank SA increased the mean evaluation from 4.1 to 4.6 (the biggest growth in researched apps) and Getin Mobile by Getin Noble SA 
increased the mean evaluation from 3.8 to 4.1. One app - Bank Millennium by Bank Millennium SA kept the good score of 4.6. The other apps all declined in mean evaluation.

The next researched sector was insurance. One company belongs to the research sample, it is the PZU SA. However, the apps offered by this company changed entirely within the researched period. Therefore, it is not possible to present the results of the comprehension between 2016 and 2018 for this company

The third researched sector was mobile telephony. The results of the comprehension between 2016 and 2018 are presented in Table 2.

Table 2. The comprehension of the mean evaluation of the most popular apps created by three mobile phone providers

\begin{tabular}{|c|c|c|c|c|c|}
\hline \multirow[b]{2}{*}{ The name of the company } & \multirow[b]{2}{*}{ Name of the app } & \multirow[b]{2}{*}{ Category } & January 2016 & August 2018 & \multirow{2}{*}{$\begin{array}{l}\text { Change } \\
\text { in the mean } \\
\text { evaluation }\end{array}$} \\
\hline & & & \multicolumn{2}{|c|}{$\begin{array}{c}\text { mean evaluation } \\
(1 \text { - very bed, } 5 \text { - very good })\end{array}$} & \\
\hline \multirow{2}{*}{ Polkomtel SA } & Plus online & tools & 3.9 & 3.6 & -0.3 \\
\hline & Nawigacja Plus & travel \& local & 3.6 & 4.1 & 0.5 \\
\hline \multirow{2}{*}{ T-Mobile Polska SA } & Mój T-Mobile & communication & 3.3 & 3.3 & 0 \\
\hline & Nawigacja T-Mobile & tools & 3.7 & 4.2 & 0.5 \\
\hline \multirow{2}{*}{ ORANGE POLSKA SA } & Mój Orange & Tools & 3.8 & 3.6 & -0.2 \\
\hline & Nawigacja Orange & travel \& local & 3.3 & 3.9 & 0.6 \\
\hline
\end{tabular}

Source: own elaboration.

In the case of mobile telephony providers, the main app designed for direct interaction with the customers remained at relatively low level in the case of one provider (T-mobile Polska SA) and decreased in the case of Polkomtel SA and Orange Polska SA. There is however some increase in the other type of the app these companies offer their customers - navigation. The means evaluations of these apps increased significantly.

\section{Research limitation}

The first limitation of the research is the fact that the research was conducted on one platform only - Android. It is the biggest operation system in the world. However, the research did not include the second system - iOS. The results for iOS may be different.

Another research limitation is caused by dynamic changes in the mobile apps market. As some of the apps changed during the 20 months period of study (for example a company changed their brand and introduced a new app or the old app was removed and replaced with an entirely new one), only the apps that existed both in January 2016 and October 2018 were taken into account. Therefore the research may not include new apps, that can be better (or worse) in the eyes of the consumers.

The next limitation is related to the assumption that the mean evaluation of an app is directly correlated with the overall user satisfaction. There may be some other factors, which require some additional research.

\section{Conclusions}

For researched companies the following conclusion can be drawn from the conducted research:

1. Most of the researched companies are aware of the mobile marketing and importance of mobile apps as a new, interactive channel of reaching the audience, as they all offer various mobile apps. 
2. With some exceptions, which may be seen as best practices, most of the researched apps' mean evaluation decreased.

3. The fact that the mean evaluation of analyzed apps decreased constitutes a serious thread for researched service companies, as it may indicate a poor level of satisfaction of their customers from their mobile marketing actions. In the context of growing importance of mobile marketing this thread should be taken seriously.

According to the literature, there are many advantages of mobile marketing as compared with other marketing programs (Berman, 2016). Mobile marketing is always on, always connected, and always with the consumer (marketers can generate offers based on special weather conditions and natural disasters, can quickly match a competitor's price offer or use short-term price reductions to reduce inventory levels and can quickly assess the effectiveness of different campaigns); mobile marketing is able to generate locationsensitive offers (marketers can develop special offers to consumers within a given distance to both its own and competitors' retail locations and can provide special product information to consumers within a specific aisle); mobile marketing can send relevant personalized messages and offers (marketers can tailor messages and offers can be tailored to each consumer based on their purchase history, social media usage, demographic data, and usage data and can present different offers to current consumers, heavy users, lapsed users, relationship customers, and transactional customers). The poor performance of the apps can make it very difficult or even impossible to fully utilize these advantages. Therefore, the following recommendations for the future actions can be drawn:

1. To utilize the potential of mobile marketing the companies should improve their apps and offer new ones in order to strengthen the relations with stakeholders.

2. There is an immediate need to understand the causes of the significant decrease in the mean evaluation of the apps

3. There should be significant work put on the quality and usability of the offered apps.

4. The comments made by users should be analyzed carefully to understand their opinions and behaviors.

\section{References}

Berman, B. (2016). Planning and implementing effective mobile marketing programs. Business Horizons, 59, 431-439.

Gracz, L. (2016). The Role of Mobile Apps in Contemporary Marketing in Poland. Handel Wewnętrzny, 4 (363), 33-43.

Kim, S., Baek, T.H. (2018). Examining the antecedents and consequences of mobile app engagement. Telematics and Informatics, 35 , 148-158.

Kuan-Yu, Ch., Yu-Lun, H. (2012). Mobile phone applications as innovative marketing tools for hotels. The International Journal of Organizational Innovation, 5 (2), 116-140.

Kumar, D.S., Purani, K., Viswanathan, S.A. (2018). Influences of 'appscape' on mobile app adoption and m-loyalty. Journal of Retailing and Consumer Services, 45, 132-141.

Liu, F., Zhao, S., Li, Y. (2017). How many, how often, and how new? A multivariate profiling of mobile app users. Journal of Retailing and Consumer Services, 38, 71-80.

Mobile Marketing Association (2018). Retrieved from: https://www.mmaglobal.com/news/mma-updates-definition-mobile-marketing.

Palomba, F., Linares-Vásquez, M., Bavota, G., Oliveto, R., DiPenta, M., Poshyvanyk, D., DeLucia, A. (2018). Crowdsourcing user reviews to support the evolution of mobile apps. The Journal of Systems and Software, 137, 143-162.

Pentina, I., Zhang, L., Bata, H., Chen, Y. (2016). Exploring privacy paradox in informationsensitive mobile app adoption: a cross-cultural comparison. Computers in Human Behavior, 65, 409-419.

Polska.jest.mobi (2018). Retrieved from: www.jestem.mobi. 
Qin, M., Tang, Ch., Jang, S., Lehto, X. (2017). Mobile app introduction and shareholder returns. Journal of Hospitality and Tourism Management, 31, 173-180.

Taylor, D.G., Voelker T.A., Pentina, I. (2011). Mobile application adoption by young adults: A social network perspective. International Journal of Marketing, 6 (2), 60-70.

Zhao Z., Balague Ch. (2015). Designing branded mobile apps: Fundamentals and recommendations. Business Horizons, 58, 305-315.

Cite this anticle aS: Gracz, L. (2018). The users perception of mobile apps of polish biggest service companies. European Journal of Service Management, 4 (28/2), 179-185. DOI: 10.18276/ejsm.2018.28/2-22. 